\title{
SEROLOGICAL AND GENETIC DIVERSITY AMONGST SALMONELLA STRAINS ISOLATED IN A SALAMI PROCESSING LINE
}

\author{
Vinicius B. Ribeiro ${ }^{1 *}$; Cristiano Andrigheto ${ }^{1}$; Luciano S. Bersot ${ }^{2}$; Vinicius Barcellos ${ }^{2}$; Eliana F. Reis ${ }^{3}$; \\ Maria T. Destro ${ }^{1}$
}

${ }^{1}$ Departamento de Alimentos e Nutrição Experimental, Faculdade de Ciências Farmacêuticas, Universidade de São Paulo, Brazil; ${ }^{2}$ Laboratório de Controle Microbiológico de Água e Alimentos, Universidade Federal do Paraná, Brazil; ${ }^{3}$ Laboratório de Enterobactérias, Fundação Oswaldo Cruz - FIOCRUZ, RJ, Brazil

Submitted: April 28, 2006; Returned to authors for corrections: July 13, 2006; Approved: January 18, 2007

\begin{abstract}
Salmonella is one of the most important agents of foodborne disease in Brazil and in other countries, with meat and meat products being identified as important vehicles of salmonelosis. A total of 54 Salmonella strains isolated from a commercial salami processing line were first serotyped and then their antibiotic resistance and macro restriction profiles were determined. $11.1 \%$ of the strains showed resistance to 3 or more antibiotics with profile AmpCStxTe being the most frequent. PFGE generated 9 and 12 profiles with enzymes XbaI and SpeI, respectively. It was observed that different serotypes of Salmonella could be found in the different steps of the processing line. The genetic profile of the strains had low relationship indicating the genetic diversity of the tested strains.
\end{abstract}

Key-words: Salmonella sp., salami, PFGE

\section{INTRODUCTION}

Salmonella is one of the most important cause of foodborne disease in Brazil, being responsible for several outbreaks in recent years (14). Poultry, eggs and their products are the main vehicles of the pathogen. However, red meat and meat products, such as salami, have also been involved (21).

In order to produce safer products companies ought to identify the pathogen sources in the different steps of the production chain. Subtyping bacterium isolates using serotyping, phagetyping (19) and antimicrobial resistance profile are good tools for that (7). The epidemiological relationship amongst the isolates allows the identification of places in the processing line where one lineage appears or disappears, revealing stages that contributes to final contamination of the product (6).

Methods that allow evaluating genotypic differences amongst strains have gained importance in the 80's. Pulsedfield gel electrophoresis (PFGE) (16) is one of the most used genetic methods to subtype microorganisms, such as
Salmonella. The main advantages of PFGE are the high discriminatory power, reproducibility and profile stability $(8,13)$. PFGE databases can be generated and store submitted genetic profiles, allowing epidemiological surveillance not only in regional scale, but also national or international levels. In this context it was created, for example, the PulseNet data base (18).

This study aimed to evaluate the serological and genetic diversity of Salmonella strains isolated in a commercial salami processing line.

\section{MATERIALAND METHODS}

\section{Bacterial isolates}

All Salmonella isolates $(\mathrm{n}=54)$ were isolated from samples collected in a commercial salami processing line located in Paraná (Brazil) during 2002 and 2003. Samples were obtained from five points along the processing line including ground meat, seasonings, raw salami after stuffing, salami after curing and salami after smoking.

*Corresponding Author. Mailing address: Departamento de Alimentos e Nutrição Experimental, Faculdade de Ciências Farmacêuticas. Av.Prof. Lineu Prestes, 580 Bairro Cidade Universitária. 05508-900. Tel.: (11) 3091-2191 / (11) 3815-4410. E-mail: viniciusbuccelli@yahoo.com.br 
All the isolates were serotyped at the Enterobacteriaceae Laboratory of Fundação Oswaldo Cruz (FIOCRUZ), Rio de Janeiro, Brazil. One Salmonella Enteritidis strain (ATCC 13076) was used as PFGE control.

\section{Antimicrobial resistance profile}

The disc diffusion assay was conducted using commercial disks (Oxoid, UK) and according to the US CLSI (11). The following agents were tested: amikacin (Ak), $30 \mu \mathrm{g}$; ampicillin (Amp), $10 \mu \mathrm{g}$; cefotaxime (Ctx), $30 \mu \mathrm{g}$; cefoxitin (Fox), $30 \mu \mathrm{g}$; ceftazidime (Caz), $30 \mu \mathrm{g}$; ciprofloxacin (Cip), $5 \mu \mathrm{g}$; chloramphenicol (C), $30 \mu \mathrm{g}$; enrofloxacin (Enr), $5 \mu \mathrm{g}$; imipenem (Ipm), $10 \mu \mathrm{g}$; sulfamethoxazole/trimethoprim (Stx), $25 \mu \mathrm{g}$; tetracycline (Te), $30 \mu \mathrm{g}$.

\section{PFGE}

PFGE was performed according to the US PulseNet protocol (3). A single colony of each isolate was streaked on tryptic soy agar (TSA) (Oxoid, UK) and incubated overnight at $37^{\circ} \mathrm{C}$. A portion of the growth was transferred to Cell Suspension Buffer (CSB; $100 \mathrm{mM}$ Tris- $\mathrm{HCl}, 50 \mathrm{mMEDTA}, \mathrm{pH} 8$ ) and the concentration of cells adjusted to 1,3-1,4 ( $\left.\mathrm{A}_{600}\right)$ in a Ultrospec 2000 (Amersham Biosciences, UK). Immediately, $200 \mu \mathrm{l}$ of the adjusted cell suspension was transferred to $1.5 \mathrm{ml}$ micro-centrifuge tubes, 200 $\mu \mathrm{g}$ of proteinase K (New England Biolabs, USA) were added and subsequently mixed with $1 \%$ Seakem Gold Agarose (Amersham Biosciences, Sweden) in TE Buffer (10 mM Tris-HCl, 1 mMEDTA, $\mathrm{pH} 8$ ) and $1 \%$ SDS. The mix was pipetted into disposable plug moulds. The plugs were transferred to polypropylene screwtubes with $5 \mathrm{ml}$ of Cell Lysis Buffer $(50 \mathrm{mM}$ Tris- $\mathrm{HCl}, 50 \mathrm{mM}$ EDTA, pH 8, $1 \%$ sarcosyl $)$ and $25 \mu \mathrm{l}$ of proteinase $\mathrm{K}(20 \mathrm{mg} / \mathrm{ml})$ and incubated at $54^{\circ} \mathrm{C}$ in a shaker for 2 hours with agitation (175 rpm). Thereafter, the plugs were washed twice with $15 \mathrm{ml}$ of sterile water and three more times with TE Buffer at $50^{\circ} \mathrm{C}$ for 15 minutes. Chromosomal DNA was digested with $50 \mathrm{U}$ of $\mathrm{XbaI}$ or SpeI (Amersham Bioscience, USA), according to manufacture instruction. Restriction fragments of DNA were separated using the CHEF DRIII (BioRad, Hercules, CA). Electrophoresis was conducted for 18 hours (initial switch time: $2.20 \mathrm{~s}$; final switch time: $63.8 \mathrm{~s})$ at $6 \mathrm{~V} / \mathrm{cm}$ and $14^{\circ} \mathrm{C}$ in $0,5 \mathrm{X} \mathrm{TBE}$ buffer with $50 \mu \mathrm{M}$ of thiourea to prevent degradation of the DNA (15).

\section{Data analysis}

PFGE profiles were visually compared and strains grouped by processing line. genetic profiles. Gel images were digitally captured using a KODAK EDAS120 system (Eastman Kodak Co., Rochester, N.Y.). Profile correlations were evaluated with NTSYSpc ver. 2.0, using Dice similarity coefficient (5) and Unweighted Pair Group Method using Arithmetic Average (UPGMA) cluster analysis (17).

\section{RESULTS AND DISCUSSION}

Salmonella Panama was the most frequent serotype found (16/54), followed by 0:4:5 (10/54), Newport (8/54) and Typhimurium (6/54) (Table 1). $S$. Panama is the most invasive serotype for children, if compared to others serotypes (22). During the serological identification it was not possible to detect the flagellar characteristics of serotypes 0:4:5 and 0:9:12, likely due to the low level of expressed antigen. Serotypes Newport and Typhimurium are considered amongst the top five Salmonella serotypes causing foodborne diseases in USA (4).

The comparison of these results with others conducted in Brazil was not possible since no reports of these serotypes in meat products were found in the literature.

The majority of the strains (46/54) $(85.2 \%)$ were sensible to all the tested antimicrobials (Table 2) two out of the 54 (3.7\%) strains showed resistance to one agent and six strains (11.1\%), all belonging to Panama serotype, presented multiple resistance to three or more agents. Profile AmpCStxTe was the most frequent (Table 2). Other authors have reported the isolation of Salmonella strains from food and clinical samples with the same profile (1).

The importance of antibiotics used in animal feed as agent of induction to the resistance to antimicrobials is questionable

Table 1. Sources and serotypes of the 54 Salmonella strains isolated in a salami

\begin{tabular}{|c|c|c|}
\hline Step & Strains & Serotype \\
\hline \multirow[t]{2}{*}{$\mathrm{P} 2$ - ground meat } & $21,22,23$ & S. Newport \\
\hline & 50,51 & S. Panama \\
\hline \multirow[t]{2}{*}{ P3 - seasonings } & $4,5,6,7,11,12,13,14,15$ & S. (O:4:5) \\
\hline & $8,9,10$ & S. Brandenburg \\
\hline \multirow[t]{3}{*}{ P4 - raw salami after stuffing } & 24 & S. (O:4:5) \\
\hline & 25 & S. Newport \\
\hline & $35,46,47$ & S. Panama \\
\hline \multirow[t]{7}{*}{ P5 - salami after curing } & 1,2 & S. Brandenburg \\
\hline & $3,16,17,18,19,27,28,39,52,53,54$ & S. Panama \\
\hline & 26 & S. Newport \\
\hline & $29,30,31,32,33,34$ & $S$. Typhimurium \\
\hline & $38,43,44$ & $S$. (rough) \\
\hline & $40,45,48,49$ & S. Ohio \\
\hline & 41,42 & S. $(\mathrm{O}: 9: 12)$ \\
\hline P6 - salami after smoking & $20,36,37$ & S. Newport \\
\hline
\end{tabular}


and it still needs further explanations. However, an efficient way for acquisition and dissemination of resistance factors is through mobile elements, including plasmids, transposons and genes cassettes located in integrons that can be transmitted through the process of bacterial conjugation. These events can be occurring as consequence of selective pressures in the processing environment of the salami (2).

PFGE divided the 54 strains in nine and 12 profiles using enzymes XbaI and SpeI, respectively (Fig .1). The nine profiles generated with the enzyme Xbal showed seven to 13 DNA fragments, with molecular weights varying from $13 \mathrm{~Kb}$ to $760 \mathrm{~Kb}$ (Fig. 1). With SpeI, 12 PFGE profiles were obtained, with 11 to

Table 2. Resistance profile to antimicrobial agents of Salmonella sp. strains isolated in a salami processing line

\begin{tabular}{|c|c|c|}
\hline Resistance profile $^{a}$ & Serotypes & $\begin{array}{l}\text { Total of } \\
\text { strains }\end{array}$ \\
\hline $\mathrm{Ak}$ & S. Brandenburg & 1 \\
\hline AmpCStxTe & S. Panama & 3 \\
\hline AmpCStxTeEnr & S. Panama & 1 \\
\hline Enr & S. enterica subsp enterica (O:4:5) & 1 \\
\hline AmpStxTe & S. Panama & 2 \\
\hline Susceptible ${ }^{b}$ & Others $^{\mathrm{c}}$ & 46 \\
\hline
\end{tabular}

${ }^{a}$ Antibiotics: amikacin (Ak), ampicillin (Amp), cloranphenicol (C), tetracycline (Te), enrofloxacin (Enr), sulfamethoxazole+trimethoprim (Stx); 'Susceptible to all the previous ones and cefotaxime (Ctx), cefoxitin (Fox), ceftazidime (Caz), imipenem (Ipm), ciprofloxacin (Cip), ${ }^{\mathrm{c}} S$. Brandenburg, $S$. Panama, $S$. Newport, $S$. Thyphimurium, $S$. Ohio, $S$. enterica ssp. enterica (rough), S. enterica ssp. enterica serotype O:4:5; S. enterica ssp. enterica serotype O:9:12.
15 bands and molecular weights varying from $19 \mathrm{~Kb}$ to $652 \mathrm{~Kb}$ (Fig. 1).

Genetic typing of Salmonella sp. has proved to be a useful tool in the characterization of different serotypes of Salmonella. It is also useful to access the distribution of the pathogens along a food production line (10).

Combining the results obtained with the two enzymes, the 54 strains could be allocated in 12 profiles that were used in generating the dendogram (Fig. 2) where two clonal groups can be identified (A, B).

Although this study have allowed the differentiation interserogroups and intraserogroups, in some clusters this did not occur, for example in clusters A1 and B1 (Fig. 2). This limitation also was observed by NAYAK et al. (12) that using PFGE had found in the same genetic profile strains belonging to different serogroups.

It is interesting to note that isolates from the same serotype can belong to different PFGE profiles. For example, strains of Salmonella Panama were allocated in combined profiles C2, C7, $\mathrm{C} 10$ and $\mathrm{C} 12$ (Fig. 2) with the latter showing low genetic similarity with the formers. These differences can indicate the occurrence of chromosomal rearrangements, loss or acquisition of plasmids or even the occurrence of punctual mutations. PFGE can be important to detect genetic events responsible for the genetic variability $(9,20)$. Those fragments of DNA that allowed the differentiation of strains $\mathrm{C} 2$ and $\mathrm{C} 12$, for example, could be carrying resistance genes to antibiotics since the two profiles showed different multiresistance (Fig. 2).

It can be seen in the dendrogram that, in general, there was low genetic similarity amongst the strains indicating that they could be from different sources, even belonging to the same serotype.
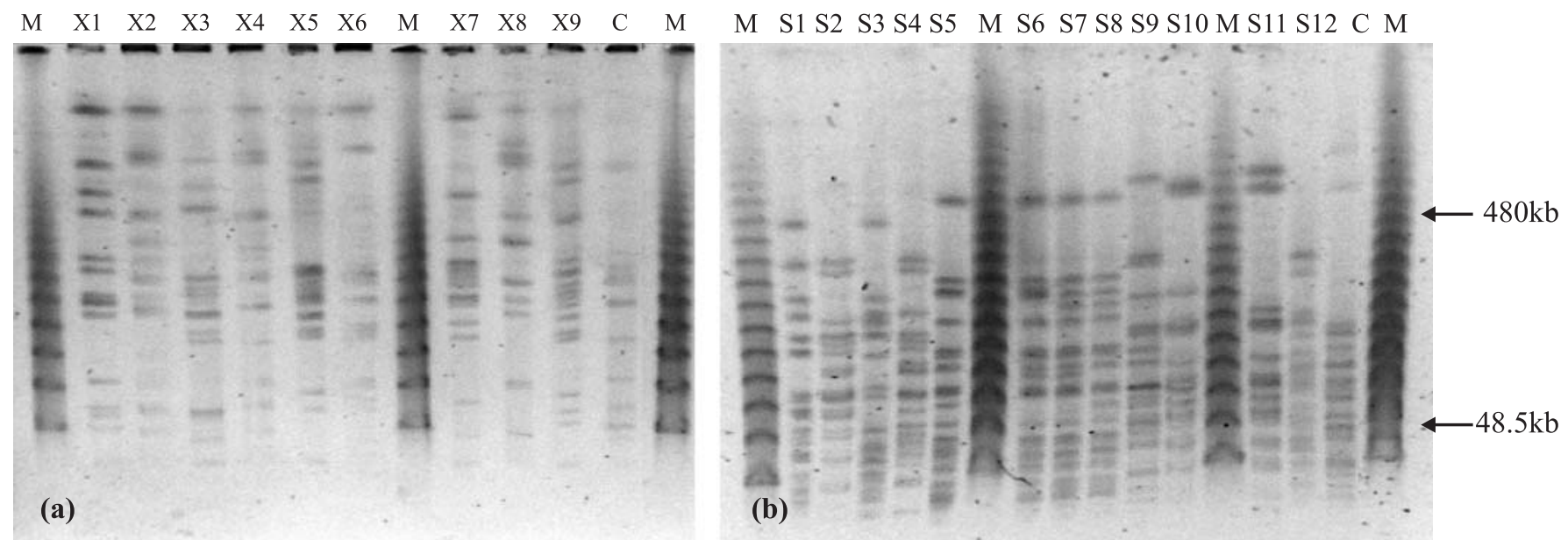

Figure 1. PFGE profiles obtained with restriction enzyme XbaI (a) and SpeI (b) for the 54 strains of Salmonella sp. M= Marker (Lambda ladder PFGE Marker). C = Salmonella Enteritidis ATCC 13076. 


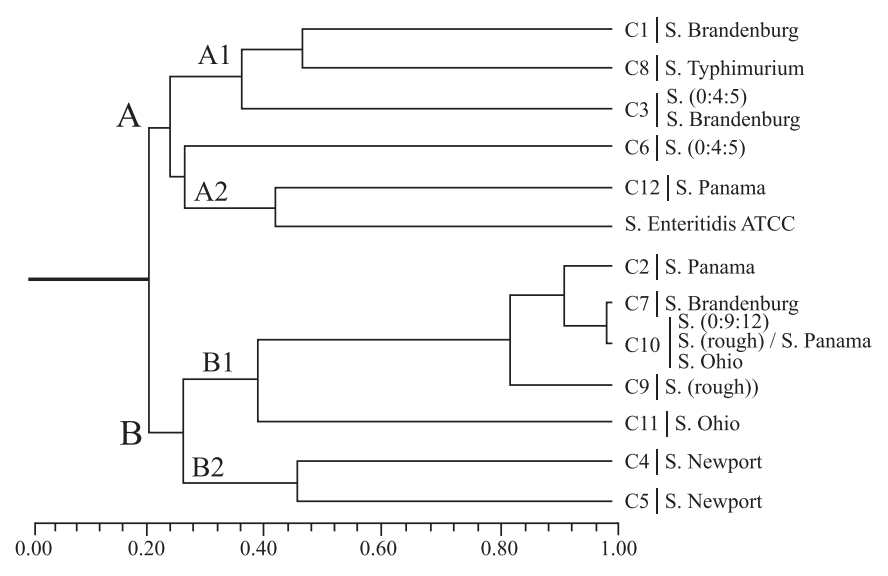

Figure 2. Genetic relationship amongst the 12 combined PFGE profiles obtained for the Salmonella sp. strains.

Our findings indicate that eliminating Salmonella from this processing plant will be a difficult task since it came from different sources. The company needs to implement effective sanitary actions and also take preventive measures to avoid the presence of the pathogens in the final product. On top of that, the occurrence of multi-resistant strains is another cause of concern for public health.

\section{ACKNOWLEDGEMENTS}

The authors are grateful to Fundação de Amparo à Pesquisa do Estado de São Paulo (FAPESP) for the fellowship (Proc. 03/ 09316-9) to the first author.

\section{RESUMO}

\section{Diversidade sorológica e genética de cepas de salmonella sp. Isoladas em uma linha de produção industrial de salame}

Salmonella é um dos principais agentes de enfermidades transmitidas por alimentos (ETA) no Brasil e em outros países, sendo os derivados cárneos frequentemente associados como veículos de surtos de salmonelose. Um total de 54 cepas de Salmonella sp., isoladas a partir de amostras de salame coletadas nas diferentes etapas de uma linha de produção industrial, foram sorotipadas e posteriormente caracterizadas quanto a sua sensibilidade a antimicrobianos e perfil PFGE. Entre as cepas avaliadas, $11,1 \%$ apresentaram resistência a três ou mais dos antimicrobianos, sendo o perfil AmpCStxTe mais freqüente. Foram obtidos 9 e 12 perfis PFGE, empregando-se as enzimas XbaI e SpeI, respectivamente. Os perfis de ambas as enzimas foram agrupados, obtendo-se 12 perfis PFGE combinados que puderam ser separados em dois grupos empregando-se a análise de UPGMA. A linha de produção industrial de salame avaliada apresentou etapas em que há contaminação por diferentes sorotipos de Salmonella sp. Os perfis genéticos encontrados indicam origens distintas para muitas cepas estudadas, uma vez que estes foram pouco relacionados entre si.

Palavras-chave: Salmonella sp., salame, PFGE

\section{REFERENCES}

1. Adley, C.C., Gorman, R. (2004). Characterization of Salmonella enterica serotype Thyphimurium isolates from human, food and animal sources in the republic of Ireland. J. Clin. Microbiol., vol. 42(5), 2314-2316.

2. Antunes, P.; Machado, J.; Sousa, J.C.; Peixe, L. (2004). Dissemination amongst humans and food products of animal origin of a Salmonella Thyphimurium clone expressing an integron-borne OXA-30. J. Antimicrob. Chemoter., 54(2), 429-34.

3. Centers for disease control. (2000). One-day (24-28 h) standardized laboratory protocol for molecular subtyping of Escherichia coli O157:H7 by pulsed field gel electrophoresis (PFGE). In:

PulseNet: The national molecular subtyping network for foodborne disease surveillance. Atlanta: Centers for Disease Control. Section, 5(11), 1-14.

4. Centers for disease control and prevention. Summary of Notifiable Diseases - United States. MMWR, Vol 52, No 54;1, 2003. Available in: www.cdc.gov/mmwr/preview/mmwrhtml/mm5254a1.htm (consulted 03/17/2005).

5. Dice, L.R. (1945). Measures of the amount of ecologic association between species. Ecology, New York, 26, 297-302.

6. Dodd, C.E.R. (1994). The application of molecular typing techniques to HACCP, Trends Food Sci. Technol., 5, 160-164.

7. Hakanen, A.; Kotilainen, P.; Houvinen, P.; Helenius, H.; Siitonen, A (2001). Reduced Fluoroquinolone susceptibility in Salmonella enterica serotypes in travelers returning from Southeast Asia. Emerg. Infect. Dis., 7(6), 996-1003.

8. Laconcha, I.; Baggesen, D.L.; Rementeria, A.; Garaizar, J. (2000) Genotypic characterization by PFGE of Salmonella enterica serotype Enteritidis phage types 1, 4, 6, and 8 isolated from animal and human sources in three European countries. Vet. Microbiol., 75, $155-165$

9. Lukinmaa, S.; Nakari, U.M.; Eklund, M.; Siitonen, A. (2004). Application of molecular genetic methods in diagnostics and epidemiology of food-borne bacterial pathogens. APMIS. 112(1112), 908-29

10. Millemann, Y.; Lesage, M.; Chaslus, E. (1995). Value of plasmid profile, ribotyping and detection of IS200 for tracing avian isolates of Salmonella Typhimurium and Enteritidis. J. Clin. Microbiol., 33, 173-179.

11. Clinical and Laboratory Standards Institute (CLSI). (2002). Performance standards for antimicrobial susceptibility testing; 12th informational supplement. CLSI document M100-S12. Wayne: NCCLS. 22(1), 136p.

12. Nayak, R.; Stewart, T.; Wang, R.F.; Lin, J.; Cerniglia, C.E.; Kenney, P.B. (2004). Genetic diversity and virulence genes determinants of antibiotic-resistant Salmonella isolated from preharvest turkey production source. Int. J. Food Microbiol., 90, 51-62.

13. Olive, D.M.; Bean, P. (1999). Principles and applications of methods for DNA-based typing of microbial organisms. J. Clin. Microbiol., 37(6), 1661-1669.

14. Sistema de Informacion para la vigilancia de las enfermedades transmitidas por los alimentos. SIRVETA. http:// www.panalimentos.org/sirveta/e/ report_eta01.asp 
15. Romling, U.; Tummler, B.; (2000). Achieving $100 \%$ typeability of Pseudomonas aeruginosa from patients with recurrent Gram negative bacteremia. Diagn. Microbiol. Infect. Dis., 25, 1-8.

16. Schwartz, D.C.; Cantor, C.R. (1984). Separation of yeast chromosome-sized DNAs by pulsed field gradient gel electrophoresis. Cell, 37, 67-75.

17. Sneath, P.H.A.; Sokal, R.R. (1973). Numerical Taxonomy. San Francisco: Freeman, 573p.

18. Swaminathan, B.; Barret, T.J.; Hunter, S.B.; Tauxe, R.V.; CDC PULSENET TASK FORCE. (2001). PulseNet: the molecular subtyping network for foodborne bacterial disease surveillance, United States. Emerg. Infect. Dis., 7(3), 382-389.

19. Ward, L.R.; De Sá, J.D.H.; Rowe, B. (1987). A phage typing scheme for Salmonella Enteritidis. Epidemiol. Infect., 99, 291-294.
20. Weigel, R.M.; Qiao, B.; Teferedegne, E.B.; Suh, D.K.; Barber, D.A.; Isaacson, R.E.; White, B.A. (2004). Comparison of pulsed field gel electrophoresis and repetitive sequence polymerase chain reaction as genotyping methods for detection of genetic diversity and inferring transmission of Salmonella. Vet. Microbiol., 100, 205-217.

21. Willians, R.C.; Isaacs, S.; Decou, M.L.; Richardson, E.A.; Buffett, M.C.; Slinger, R.W.; Brodsky, M.H.; Ciebin, B.W.; Ellis, A.; Hockin, J. (2000). Illness outbreak associated with Escherichia coli O157:H7 in Genoa salami. E. coli O157:H7 working group. CMAJ, 162(10), 1409-1413.

22. Yang, Y.J.; Huang, M.C.; Wang, S.M.; Wu, J.J.; Cheng, C.P.; Liu, C.C. (2002). Analysis of risk factors for bacteremia in children with nontyphoidal Salmonella gastroenteritis. Eur. J. Clin. Microbiol. Infect. Dis., 21, 290-93. 